Article

\title{
Revised SEDD (RSEDD) Model for Sediment Delivery Processes at the Basin Scale
}

\author{
Walter Chen *(D) and Kent Thomas $(\mathbb{D}$ \\ Department of Civil Engineering, National Taipei University of Technology, Taipei 10608, Taiwan; \\ t107429401@ntut.edu.tw \\ * Correspondence: waltchen@ntut.edu.tw; Tel.: +886-2-2771-2171 (ext. 2628)
}

Received: 18 May 2020; Accepted: 15 June 2020; Published: 17 June 2020

\begin{abstract}
Sediment transport to river channels in a basin is of great significance for a variety of reasons ranging from soil preservation to siltation prevention of reservoirs. Among the commonly used models of sediment transport, the SEdiment Delivery Distributed model (SEDD) uses an exponential function to model the likelihood of eroded soils reaching the rivers and denotes the probability as the Sediment Delivery Ratio of morphological unit $i\left(S D R_{i}\right)$. The use of probability to model $S D R_{i}$ in SEDD led us to examine the model and check for its statistical validity. As a result, we found that the SEDD model had several false assertions and needs to be revised to correct for the discrepancies with the statistical properties of the exponential distributions. The results of our study are presented here. We propose an alternative model, the Revised SEDD (RSEDD) model, to better estimate $S D R_{i}$. We also show how to calibrate the model parameters and examine an example watershed to see if the travel time of sediments follows an exponential distribution. Finally, we reviewed studies citing the SEDD model to explore if they would be impacted by switching to the proposed RSEDD model.
\end{abstract}

Keywords: soil erosion; sediment delivery ratio; SEDD; RSEDD

\section{Introduction}

Surface soil erosion is a major threat to food production and the environment, and the problem has been compounded by climate change in recent years. As the weather becomes more unpredictable and extreme, soil erosion is expected to increase more rapidly and therefore to become more damaging in the future. Furthermore, when the eroded soils or sediments are carried away by overland flow to navigable rivers, they also create significant problems for the safe navigation and the proper use of waterways. In the case of non-navigable rivers (such as those leading to reservoirs), the situation is worse. The accumulation of sediments can be a major origin of non-point source pollution, critically affecting water supply and demand in the region. Because of the damaging consequences of soil erosion, establishing a model to assess the creation and transport of sediments is vitally important at the basin scale, and it has been a topic of research for the last quarter-century.

\subsection{SEDD Model}

Sediment Delivery Ratio (SDR) is the ratio between the sediment yield at the basin outlet and the gross erosion of the basin. There are several basin-scale sediment delivery models, such as the SEdiment Delivery Distributed (SEDD), the Unit Stream Power Based Erosion Deposition (USPED), and the WaTEM/SEDEM models. The WaTEM/SEDEM is a soil erosion and deposition model developed and extended by KU Leuven [1-3]. This model considers the transport capacity of sediments and the flow routing according to topological changes to determine whether the dominant process for each grid cell is deposition or erosion. Similar to WaTEM/SEDEM, the USPED model assumes that the soil erosion rate and flow accumulation are transport capacity limited [4-7]. The LS factor of the Universal 
Soil Loss Equation (USLE) model is modified with the upslope contributing area to determine the transport capacity function (T). In the USPED model, the divergence of the transport capacity index $(\Delta \mathrm{T})$ for each grid cell determines whether deposition or erosion is the dominant process. Finally, the SEDD model was proposed by Ferro and Porto [8], although its formulation can be traced back to Ferro and Minacapilli [9]. Based on probability, the authors of SEDD hypothesized that "the Sediment Delivery Ratio, $S D R_{i}$, of each morphological area is a measurement of the probability that the eroded particles arrive from the considered area into the nearest stream reach" [9]. Furthermore, the authors defined the travel time as "the time that particles eroded from the source area and transported through the hillslope conveyance system take to arrive at the channel network" [9]. Assuming that $F_{i}$ is the cumulative distribution function (CDF) of the travel time $t_{p, i}$, the authors assert that the relationship between $\ln F_{i}$ and $t_{p, i}$ is linear. Then, they support the assertion with data from seven Sicilian basins. As a result, the following exponential function was used to describe the relationship between the $S D R_{i}$ and the travel time:

$$
S D R_{i}=e^{-\beta t_{p, i}}
$$

where $S D R_{i}$ is the SDR of morphological unit $i, \beta$ is a constant for a given basin $(1 / \mathrm{m})$, and $t_{p, i}$ is the travel time of morphological unit $i(\mathrm{~m})$ and defined as:

$$
t_{p, i}=\frac{l_{p, i}}{\sqrt{s_{p, i}}}=\sum_{j=1}^{N_{p}} \frac{\lambda_{i, j}}{\sqrt{s_{i, j}}}
$$

where $s_{p, i}=$ the slope of the hydraulic path $(\mathrm{m} / \mathrm{m}), l_{p, i}=$ the length of the hydraulic path $(\mathrm{m})$. Combining Equations (1) and (2), $S D R_{i}$ can be represented as:

$$
S D R_{i}=e^{-\beta t_{p, i}}=e^{-\beta \frac{l_{p, i}}{\sqrt{s_{p, i}}}}=e^{-\beta \sum_{j=1}^{N p} \frac{\lambda_{i, j}}{\sqrt{s_{i, j}}}}
$$

where $N_{p}=$ the number of morphological units localized along the hydraulic path $j$, and $\lambda_{i, j}$ and $s_{i, j}=$ the length $(\mathrm{m})$ and slope $(\mathrm{m} / \mathrm{m})$ of each morphological unit $i$ localized along the hydraulic path $j$.

Many studies have used Equations (1)-(3) and the subsequent $S D R_{w}$ (SDR for the entire basin) to estimate the movement of sediments and their impact on particular watersheds [10-14]. However, our examination of the SEDD model led us to believe that the model might have been inadequately formulated to represent the probability concept declared. We will show why we think so and present our revised version of the model in the following sections.

\subsection{Incorrect Assertions of SEDD}

There are several improper assumptions and false assertions of SEDD:

(a) "the Sediment Delivery Ratio, $S D R_{i}$, of each morphological area is a measurement of the probability that the eroded particles arrive from the considered area into the nearest stream reach" [9];

(b) the $S D R_{i}$ equation is an exponential distribution (exponential probability distribution);

(c) "the relationship between $\ln F_{i}$ and $-t_{p, i}$ is linear" [9];

(d) "the probability that the eroded particles arrive from the morphological unit into the nearest stream reach is assumed proportional to the probability of non-exceedance of the travel time, $t_{p, i}{ }^{\prime \prime}[9]$

(e) the $\beta$ coefficient can be lumped together with "the effects due to roughness and runoff along the hydraulic path" [8];

(f) the $F_{i}$ is a CDF of the travel time represented by Equation (2). 
It was further asserted by Ferro and Minacapilli [9] that:

$$
\beta_{i}=\frac{-\ln F_{i}}{t_{p, i}}
$$

These incorrect assertions will be discussed in Section 2.2.

\section{Analysis}

We will start by describing the statistical properties of exponential functions and distributions, outline the potential issues of the SEDD model, and explain how to formulate a Revised SEDD (RSEDD) model.

\subsection{Properties of Exponential Distributions}

The exponential function has a nice property concerning its differentiation and integration:

$$
\begin{gathered}
\frac{d}{d x}\left(e^{x}\right)=e^{x} \\
\int e^{x} d x=e^{x}+C
\end{gathered}
$$

where $e^{x}$ is the exponential function and $C$ is a constant.

In other words, the differentiation and integration of an exponential function is still an exponential function. Exponential functions play a crucial role in statistical analysis. For example, if a probability distribution takes the form of an exponential function, its probability distribution function (or probability density function, PDF) will be an exponential distribution. The exponential distribution is generally written as:

$$
f(x)=\lambda e^{-\lambda x} \quad x \geq 0 \text { and } \lambda>0
$$

where $f(x)$ denotes a PDF, the curve of a continuous probability distribution. Equation (7) is also called the exponential PDF. Note the difference between exponential functions and exponential distributions. It is also worth noting that the value $f(x)$ is known as the probability density at $x$, not the probability at $x$. For discrete random variables, however, relative frequency is the probability density. Unfortunately, for continuous random variables, "it is not meaningful to associate a probability value with each possible outcome on a continuum. Instead, for continuous random variables we associate probability values with intervals on the continuum" [15]. For a continuous random variable, the probability at $x$ is zero. It is the area under the curve of a PDF that represents the probability of a variable falling in the corresponding interval.

The exponential distribution is a one-parameter probability distribution, which is $\lambda$. The mean of the exponential distribution is $1 / \lambda$, and the standard deviation of the exponential distribution is also $1 / \lambda$. The exponential distribution has been applied to various fields of study, such as vehicle headway distribution [16], the failure rates of air conditioning system in airplanes [17], the catchment-scale water residence time [18], and the relative species abundance [19]. The cumulative distribution function $(\mathrm{CDF})$ of the exponential distribution is:

$$
F(x)=\int_{-\infty}^{x} f(u) d u=\int_{0}^{x} \lambda e^{-\lambda u} d u=1-e^{-\lambda x} \quad x \geq 0 \text { and } \lambda>0
$$

where $F(x)$ denotes a CDF (the $F_{i}$ in SEDD). The PDF and CDF of the exponential distribution of typical values of $\lambda$ are shown in Figure 1a,b, respectively. 


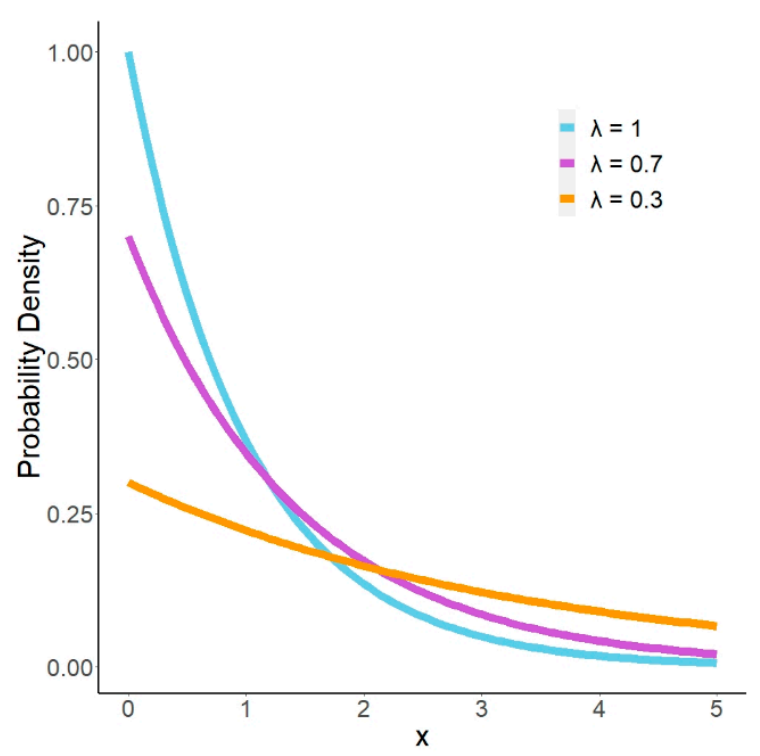

(a)

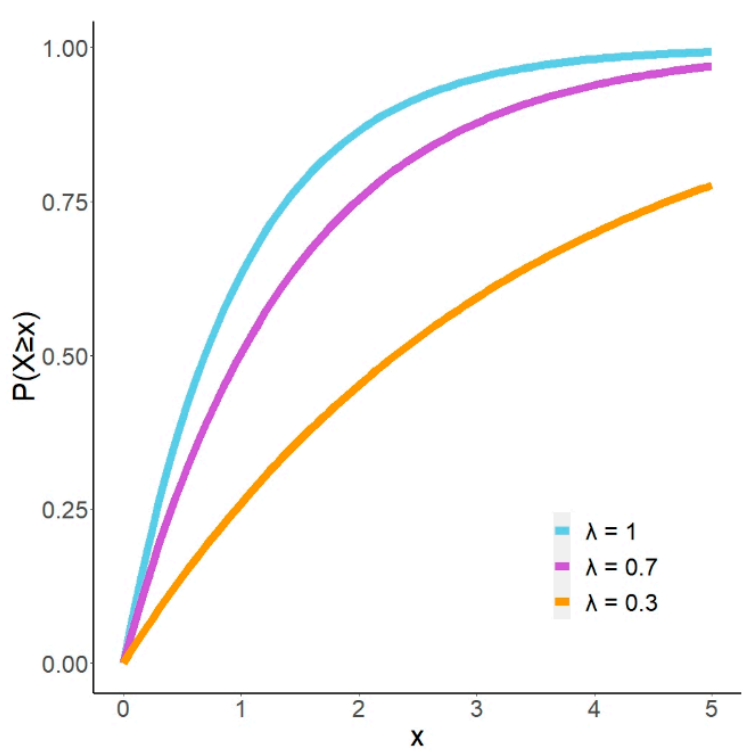

(b)

Figure 1. The (a) probability distribution function (PDF) and the (b) cumulative distribution function (CDF) of the exponential distribution of typical values of $\lambda$.

\subsection{Examination of SEDD Assertions}

The SEDD model was described in Section 1.1, and the incorrect assertions were listed in Section 1.2. We will devote this section to discussing the issues of SEDD. We will identify the potential problems that call for a revised SEDD (RSEDD) model to better suit the underlying statistical requirements for modeling $S D R_{i}$.

As mentioned earlier, using morphological units, Ferro and Minacapilli [9] considered $S D R_{i}$ as the probability that the eroded particles arrive from the source area into the nearest river channel. This seems to imply that they consider $S D R_{i}$ to be the PDF of travel time, $t_{p, i}$. On the other hand, they also wrote that the probability as mentioned above is "proportional to the probability of non-exceedance of the travel time". This statement seems to suggest that they consider $S D R_{i}$ to be the CDF of travel time instead. Although the statements might be contradictory to each other, it would not matter because neither is correct. To formulate the relationship between $S D R_{i}$ and $t_{p, i}$, the authors of SEDD decided to use an exponential function as shown in Equation (1) and repeated here as Equation (9):

$$
S D R_{i}=e^{-\beta t_{p, i}}
$$

This is probably because of the nice properties of the exponential function (Equations (5) and (6)) and the fact that they needed a linear relationship (Equation (4)) between $\ln F_{i}$ and $t_{p, i}$ to explain the observed linear data from the seven Sicilian basins. However, there are a few critical problems. First, the total area under a PDF has to be equal to one:

$$
\begin{aligned}
& \int_{-\infty}^{\infty} f(x) d x=1 \\
& f(x) \geq 0 \text { for all } \mathrm{x}
\end{aligned}
$$

Second, the CDF should be a non-decreasing function of $x$ and satisfy the following equation:

$$
\lim _{x \rightarrow+\infty} F(x)=1
$$


The integration of Equation (9) is:

$$
\int_{-\infty}^{x} S D R_{i}=\int_{-\infty}^{x} f(u) d u=\int_{0}^{x} e^{-\lambda u} d u=\frac{1}{\lambda}\left(1-e^{-\lambda x}\right)=\frac{1}{\beta}\left(1-e^{-\beta t_{p, i}}\right)
$$

Obviously, the total area under Equation (9) is not equal to one, and Equation (13) does not approach one when $x$ approaches infinity. Hence, Equation (9) is not a PDF. Moreover, since Equation (9) is not a non-decreasing function, Equation (9) is not a CDF, either. As a result, we can conclude that assertions (a), (b), (d), and (f) are incorrect.

In addition, it can be seen that the logarithm of the CDF of Equation (9) is not linear because Equation (13) is not a linear function. It can also be observed from Equation (13) that the integration (i.e., CDF) of Equation (9) is not an exponential function. Therefore, a linear relationship between $\ln F_{i}$ and $t_{p, i}$ such as that in Equation (4) does not exist. The only condition that Equation (4) is valid occurs when Equation (9) is a CDF. Since we have already shown that Equation (9) is not a CDF, we can conclude that assertion (c) and Equation (4) are incorrect.

Finally, the SEDD model assumes that $t_{p, i}$ of each morphological unit increases with the increase of the length of the hydraulic path $\left(l_{p, i}\right)$ and with the decrease of the square root of the slope of the hydraulic path $\left(s_{p, i}\right)$ :

$$
\begin{aligned}
t_{p, i} & \propto l_{p, i} \\
t_{p, i} & \propto \frac{1}{\sqrt{s_{p, i}}}
\end{aligned}
$$

Therefore, there exists a constant between $t_{p, i}$ and the product of $l_{p, i}$ and $1 / \sqrt{s_{p, i}}$. The SEDD model lumps together the constant and the $\beta$ coefficient, which changes the coefficient $\beta$ from its original meaning. Therefore, we think assertion (e) is not appropriate. We will correct these problems by presenting the Revised SEDD (RSEDD) model in the next section.

\subsection{RSEDD Model}

To distinguish from the SEDD model, we will call the following model the Revised SEDD model (RSEDD). To comply with the statistical requirements of a probability distribution function, Equation (1) is re-written as follows:

$$
S D R_{i}=\beta e^{-\beta t_{p, i}} \quad t_{p, i} \geq 0
$$

Note that $\beta$ is always positive and $t_{p, i}$ is an exponential random variable. The CDF of Equation (16) is the integration of Equation (16):

$$
F_{i}=F\left(t_{p, i}\right)=\int_{0}^{t_{p, i}} \beta e^{-\beta u} d u=1-e^{-\beta t_{p, i}} \quad t_{p, i} \geq 0
$$

We plot the natural logarithm of Y-axis values in Figure 2. The PDF and CDF of the exponential distribution of typical values of $\lambda$ are shown in Figure 2a,b, respectively. Note that the logarithm of Equation (17) is not a linear function (Figure 2b). Therefore, the relationship between $\ln F_{i}$ and $t_{p, i}$ is not linear as was suggested by the SEDD model. On the contrary, Figure 2a reveals that the natural logarithm of the exponential PDF is linear. We will use this linear property to solve for the model parameters of RSEDD later.

Recall that the original SEDD model assumes that $t_{p, i}$ of each morphological unit increases with the increase of the ratio of the length of the hydraulic path $\left(l_{p, i}\right)$ to the square root of the slope of the hydraulic path $\left(s_{p, i}\right)$. Therefore,

$$
S D R_{i}=e^{-\beta t_{p, i}}=e^{-\beta \frac{l_{p, i}}{\sqrt{s_{p, i}}}} \quad t_{p, i} \geq 0
$$




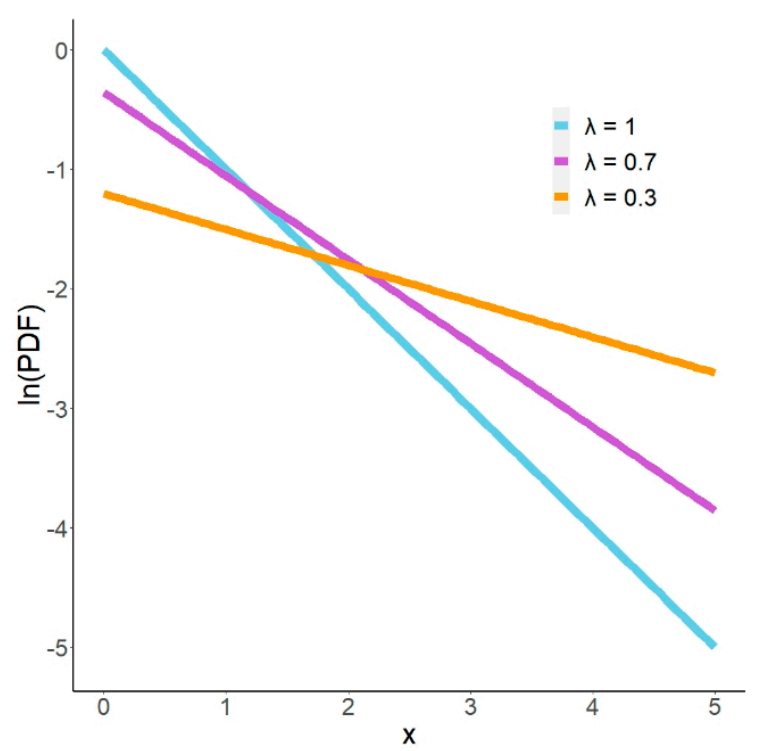

(a)

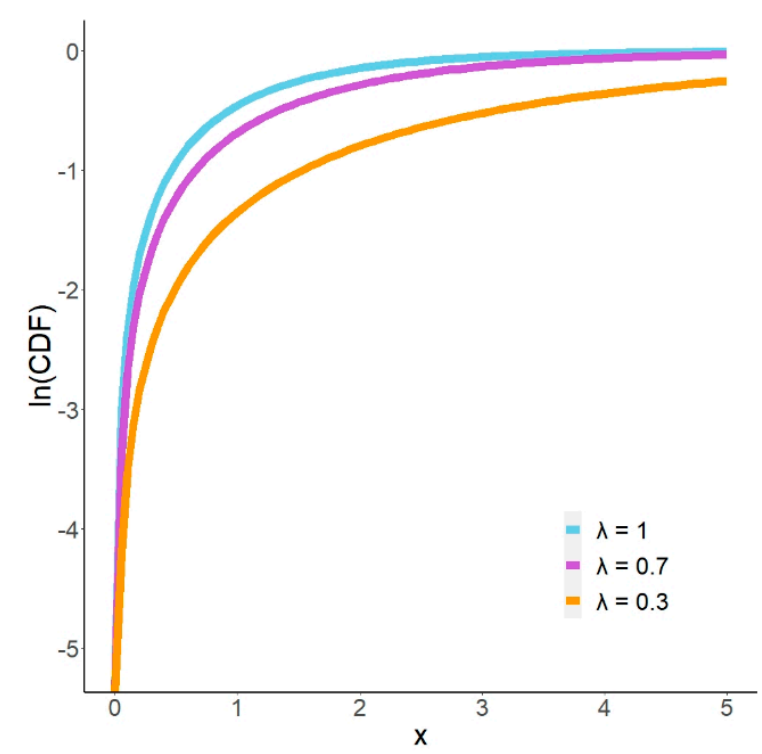

(b)

Figure 2. The natural logarithm of Figure $1 \mathrm{a}, \mathrm{b}$ (Y-axis values only). This shows that the relationship between $\ln (\mathrm{CDF})$ and $t_{p, i}$ is not linear (b), but the relationship between $\ln (\mathrm{PDF})$ and $t_{p, i}$ is linear (a).

Equation (18) holds because the SEDD model lumps together the constant between $t_{p, i}$ and $l_{p, i} / \sqrt{S_{p, i}}$ (representing "the effects due to roughness and runoff along the hydraulic path") and the $\beta$ coefficient. However, this would change the coefficient $\beta$ from its original meaning. We will introduce a new constant $k$ (dimensionless) and re-write Equation (2) as follows:

$$
\begin{gathered}
t_{p, i}=k \frac{l_{p, i}}{\sqrt{s_{p, i}}}=k d_{p, i} \\
d_{p, i}=\frac{l_{p, i}}{\sqrt{s_{p, i}}}
\end{gathered}
$$

where $d_{p, i}$ is the pseudo travel time $(\mathrm{m})$. Therefore,

$$
S D R_{i}=\beta e^{-\beta t_{p, i}}=\beta e^{-\beta k \frac{l_{p, i}}{\sqrt{s_{p, i}}}}=\beta e^{-\beta k d_{p, i}} \quad d_{p, i} \geq 0
$$

The rest is the same as the SEDD model. The exponent term has to be summed along the path traveled by the sediments from the morphological unit $i$ to the nearest river. This summation is illustrated in Figure 3 and Equation (22):

$$
\frac{l_{p, i}}{\sqrt{S_{p, i}}}=\sum_{j=1}^{N_{p}} \frac{\lambda_{i, j}}{\sqrt{S_{i, j}}}
$$

where $N_{p}=$ the number of morphological units localized along the hydraulic path $j$, and $\lambda_{i, j}$ and $s_{i, j}=$ the length $(\mathrm{m})$ and slope $(\mathrm{m} / \mathrm{m})$ of each morphological unit $i$ localized along the hydraulic path $j$.

There are two parameters ( $\beta$ and $k$ ) of the RSEDD model as shown in Equation (21). As previously shown in Figure 2, the logarithm of CDF is not linear, but the logarithm of PDF is. Therefore, to determine the model parameters, the PDF of a basin (instead of the CDF) should be used. This modification will guarantee that the new RSEDD model is a proper depiction of the exponential distribution of travel time and that $S D R_{i}$ is the "probability density" of the eroded particles arriving from the considered 
area into the nearest stream reach. To solve for model parameters $\beta$ and $k$, take the natural logarithm of Equation (21):

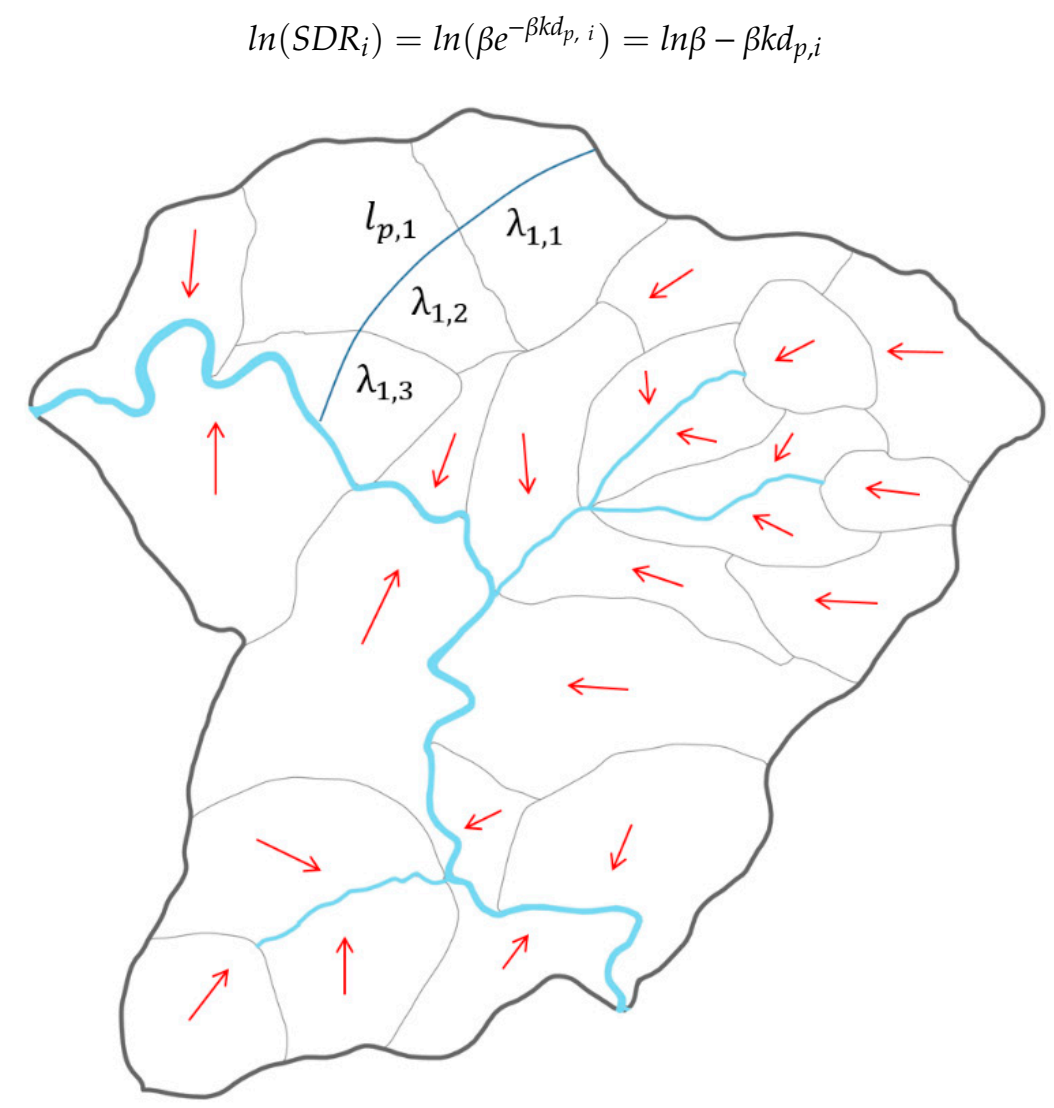

Figure 3. Illustration of the morphological unit $i$ and the path traveled by the sediments from the morphological unit $i$ to the nearest river in a basin.

Equation (23) is a linear function. By plotting $\ln \left(S D R_{i}\right)$ against $d_{p, i}$, we can determine $\beta$ from the intercept and $k$ from the slope of the linear plot (similar to Figure 2a). In other words, given $S D R_{i}$ and pseudo travel time $d_{p, i}$, we can determine $\beta$ and $k$ and use RSEDD to model sediment delivery at the basin scale.

\section{Example Watershed}

To test if the travel time follows an exponential distribution, we use a watershed from literature as an example [20]. Conceptually, the basin can be divided into morphological units with uniform gradients (and properties) as shown in Figure 4. Assuming that all units have the same gradient of 0.3 and that their hydraulic paths (arrows) are shown in Figure 5, we can calculate the slope lengths and travel times using Figure 5 and Table 1. Note that ordinary GIS software calculates the flow lengths to the outlet of the basin, but RSEDD (SEDD) calculates the flow lengths only to the river channels. Here are the null hypothesis and alternative hypothesis:

$H_{0}$ : the travel times follow an exponential distribution

$H_{a}$ : the travel times do not follow an exponential distribution 


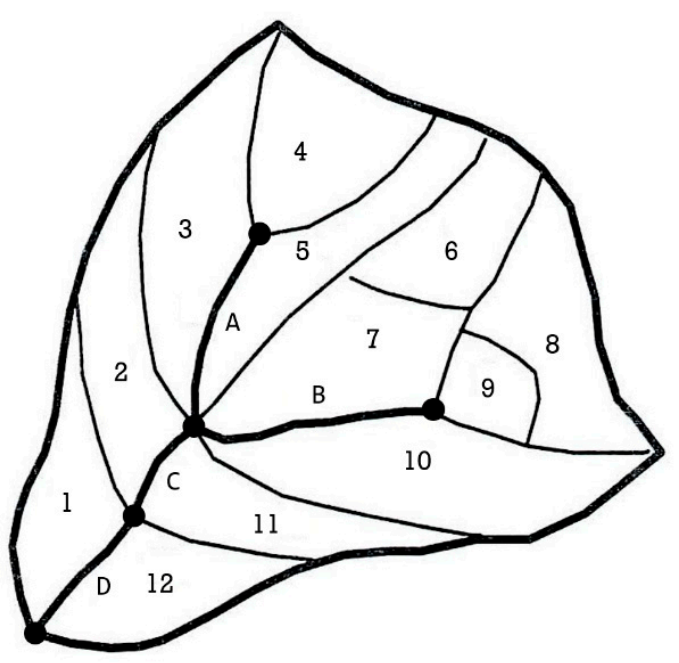

Figure 4. An example watershed (re-drawn from [20]).

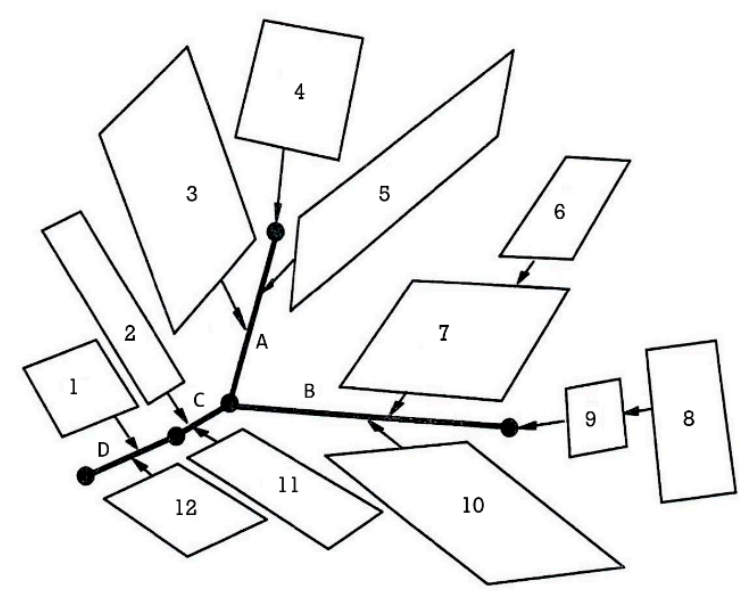

Figure 5. Divide the sample watershed in Figure 4 into morphological units and calculate the travel times (re-drawn from [20]). The arrows indicate flow directions, and the dots correspond to the dots in Figure 4.

Table 1. Pseudo travel time of each morphological area.

\begin{tabular}{cccccc}
\hline Morphological Unit & Hydraulic Path & $\lambda_{i, j}$ & $s_{i, j}$ & $\frac{\lambda_{i, j}}{\sqrt{s_{i, j}}}$ & $d_{p, i}$ \\
\hline 1 & 1 & 1.0 & 0.3 & 1.83 & 1.83 \\
2 & 2 & 2.7 & 0.3 & 4.93 & 4.93 \\
3 & 3 & 2.6 & 0.3 & 4.75 & 4.75 \\
4 & 4 & 1.6 & 0.3 & 2.92 & 2.92 \\
5 & 5 & 3.9 & 0.3 & 7.12 & 7.12 \\
6 & $6-7$ & 1.6 & 0.3 & 2.92 & 6.02 \\
7 & 7 & 1.7 & 0.3 & 3.10 & 3.10 \\
8 & $8-9$ & 0.9 & 0.3 & 1.64 & 2.92 \\
9 & 9 & 0.7 & 0.3 & 1.28 & 1.28 \\
10 & 10 & 2.6 & 0.3 & 4.75 & 4.75 \\
11 & 11 & 2.1 & 0.3 & 3.83 & 3.83 \\
12 & 12 & 1.3 & 0.3 & 2.37 & 2.37 \\
\hline
\end{tabular}

We used the Kolmogorov-Smirnov test in our statistical hypothesis testing. Reordering the $d_{p, i}$ in Table 1 from the smallest to the largest, we can calculate the cumulative distribution of our sample watershed and the corresponding cumulative distribution of the exponential distribution as shown in Table 2. For a confidence coefficient $(1-\alpha)$ of 0.95 , we obtained the sample statistic of $0.213\left(D_{n}\right)$. 
Since $D_{n}$ is not greater than the critical value of $0.375\left(D_{12,0.05}\right)$, we cannot reject the null hypothesis $\left(H_{0}\right)$ that these data come from an exponential distribution. However, we cannot accept the null hypothesis $\left(H_{0}\right)$ either because we only know a Type I error (probability equal to $\alpha=0.05$ ) and do not know the probability of making a Type II error [21]. The hypothesis testing on this example watershed is not conclusive.

Table 2. Results of the Kolmogorov-Smirnov test.

\begin{tabular}{ccccccc}
\hline & $\mathbf{x}$ & Frequency & Cumulative & Cumulative (\%) & Corresponding Exponential CDF (\%) & Difference \\
\hline & 1.28 & 1 & 1 & 0.083 & 0.284 & 0.201 \\
& 1.83 & 1 & 2 & 0.167 & 0.380 & 0.213 \\
& 2.37 & 1 & 3 & 0.250 & 0.463 & 0.213 \\
& 2.92 & 1 & 4 & 0.333 & 0.535 & 0.201 \\
& 2.92 & 1 & 5 & 0.417 & 0.535 & 0.118 \\
& 3.10 & 1 & 6 & 0.500 & 0.556 & 0.056 \\
& 3.83 & 1 & 7 & 0.583 & 0.634 & 0.050 \\
& 4.75 & 1 & 8 & 0.667 & 0.711 & 0.045 \\
& 4.75 & 1 & 9 & 0.750 & 0.711 & 0.039 \\
& 4.93 & 1 & 10 & 0.833 & 0.725 & 0.108 \\
& 6.02 & 1 & 11 & 0.917 & 0.794 & 0.123 \\
Total & 7.12 & 1 & 12 & 1.000 & 0.845 & 0.155 \\
Mean & 3.82 & & & & & 0.213 \\
$\lambda$ & 0.262 & & & & $\mathrm{D}_{n}$ & 0.375 \\
\hline
\end{tabular}

\section{Discussion}

The original studies of the SEDD model preceded several studies evaluating SDR, and its impact on geomorphology and other related issues was far-reaching. Therefore, a revision to the model would have an impact on the conclusions of some (but not all) of the publications which cited the original model. There are two different categories of impacts we have ascertained from our literature review: (a) foundation research that established and confirmed the SEDD model and validated the use of the model, and (b) studies which merely mention the SEDD model without implementation. The first category is strongly impacted by the revision of SEDD, while the revision has no impact on the second category.

The first collection of studies are studies that established, tested, and calibrated the SEDD model parameters (or its offsets, such as MOSEDD) and those studies in which SEDD plays a significant role in the procedure of the research. The first type of studies established that although there were many different gross erosion estimation models (RUSLE, USLE, USLE-M, USLE-MM, etc.), the SDR of the SEDD model was conceptually practical for estimating the sediment yield. Therefore, the specific gross erosion model considered was not particularly influential. The conclusions of these studies would require recalibration as the base model would be changed. However, the separation of the physical concept of sediment delivery and the SEDD from the gross erosion estimation concept remains intact. Alternatively, the second type of study used the SEDD model as a significant component. The conclusions and results would need to be re-evaluated to see the extent of the impact due to the use of a new model. These studies and their contributions are as follows: the relationship between channel network parameters and the sediment transport efficiency [22], the testing and calibration of the SEDD model [8,23-28], the assessment of sediment connectivity in dendritic and parallel Calanchi systems [29,30], sediment load impact on a reservoir [14], the estimation of the response to land use/cover change in a catchment [31], sediment yield in monocrop plantation areas, such as reafforested eucalyptus and olive orchards [13,32], the assessment of sediment delivery/soil erosion processes using Caesium-137 [23,33-37], testing of the correction of the topographic factors of the RUSLE [38-42], soil erosion and sediment yield estimation [10,43-58], agricultural non-point pollution [59], clay content relationship with sediment delivery [60], the assessment of the temporal variation of sediment yield [61], chemical transport in sediment delivery processes [62,63], agricultural methods impact on soil erosion and sediment yield [11,12], impact of bushfire or wildfire on soil erosion [64], comparison of multiple 
SDR models/gross erosion models [65,66], soil texture prediction [67], relating geomorphic features to soil erosion [68], landscape management and water resources management [69], and land use and impact of check dams on sediment yield [70-72].

Many studies have cited the conclusions or observations made by Ferro and Minacapilli [9] and the SEDD model within their literature review. However, they have not explicitly employed the SEDD model or the SDR equation. These represent the second collection of studies related to the SEDD model. Common citations are for the following reasons: (1) as an example of research which uses RUSLE, (2) travel time as a basis for the regionalization of SDR, (3) defining SDR, (4) sediment transport and its relationship with storage time and the sediment delivery ratio, (5) lumped sediment delivery ratio, (6) linkage between different scales using the SDR equation, (7) empirical models to evaluate sediment yield and soil erosion, (8) sediment yield being proportional to the sediment delivery processes, (9) topographic factors and their relationship with SDR, (10) spatially distributed empirical erosion models, and (11) calibration of measured and calculated sediment yields [2,68,73-129].

The preceding literature review includes all accessible papers to the authors of this study (using the Scopus database). It confirms that between 1995, the year the SEDD model was published, to 2019, there has been no revision of the SEDD model similar to what is proposed in this study. Note that there might be additional studies that have not been included in the literature review of this study because these papers utilized the SEDD model but did not reference the original study of the SEDD model [9]. For example, Diwediga et al. [130] utilized the SEDD model to study soil erosion response to sustainable land management in the Mo River Basin, Togo, Africa, but referenced the Di Stefano et al. [36] equation instead. Finally, the great influence the original paper on sediment delivery research over the past 25 years gives rise to an innumerable number of references. These references might exist in less accessible databases, conference materials, and in national/state/municipal level public research that are beyond our ability to review.

\section{Summary and Conclusions}

Using exponential distributions to model naturally occurring phenomena is quite common in natural science and engineering analysis. The use of exponential distribution to model the probability of sediments entering river channels is an essential contribution of SEDD, and the model has been widely used to study different basins in the world. However, there are several false assertions by the SEDD model, which do not seem to have been noticed in the literature. We reviewed this often used model and proposed to revise it to better suit the underlying statistical requirements. As a result, the RSEDD model was introduced with two model parameters, $\beta$ and $k$. The calibration of these parameters can be done using the logarithm of PDF. We also reviewed literature citing the SEDD model to see the impact of the revision on these studies. The first collection of studies are studies that calibrated the SEDD model parameters or used the SEDD model as a significant component of the studies. These studies need to be re-evaluated to see the extent of the impact. The second collection of studies used the SEDD model as an example or merely mentioned the model without implementation. The revision does not affect these studies. However, it remains to be seen whether the new RSEDD model can reliably predict $S D R_{i}$ and sediment yield in future watershed research.

Author Contributions: Conceptualization, W.C.; Data curation, K.T.; Formal analysis, W.C.; Funding acquisition, W.C.; Investigation, W.C. and K.T.; Methodology, W.C.; Project administration, W.C.; Resources, W.C.; Software, K.T.; Supervision, W.C.; Writing—original draft, W.C. and K.T.; Writing-review \& editing, W.C. All authors have read and agreed to the published version of the manuscript.

Funding: This study was partially supported by the National Taipei University of Technology-King Mongkut's Institute of Technology Ladkrabang Joint Research Program (Grant Number NTUT-KMITL-108-01) and the Ministry of Science and Technology (Taiwan) Research Project (Grant Number MOST 108-2621-M-027-001).

Acknowledgments: We thank Kieu Anh Nguyen, Chih-Hung Wang, and Tse-Wei Lo for assistance with manuscript preparation. We also thank the anonymous reviewers for their careful reading of our manuscript and insightful suggestions to improve the paper.

Conflicts of Interest: The authors declare no conflict of interest. 


\section{References}

1. Van Oost, K.; Govers, G.; Desmet, P. Evaluating the effects of changes in landscape structure on soil erosion by water and tillage. Landsc. Ecol. 2000, 15, 577-589. [CrossRef]

2. Van Rompaey, A.J.J.; Verstraeten, G.; Van Oost, K.; Govers, G.; Poesen, J. Modelling mean annual sediment yield using a distributed approach. Earth Surf. Proc. Landf. 2001, 26, 1221-1236. [CrossRef]

3. Verstraeten, G.; Van Oost, K.; Van Rompaey, A.; Poesen, J.; Govers, G. Evaluating an integrated approach to catchment management to reduce soil loss and sediment pollution through modelling. Soil Use Manag. 2002, 18, 386-394. [CrossRef]

4. Mitasova, H.; Hofierka, J.; Zlocha, M.; Iverson, L.R. Modeling topographic potential for erosion and deposition using GIS. Int. J. Geogr. Inf. Syst. 1996, 10, 629-641. [CrossRef]

5. Mitas, L.; Mitasova, H. Distributed soil erosion simulation for effective erosion prevention. Water Resour. Res. 1998, 34, 505-516. [CrossRef]

6. Mitasova, H.; Mitas, L. Multiscale soil erosion simulations for land use management. In Landscape Erosion and Landscape Evolution Modeling; Harmon, R., Doe, W.W., Eds.; Springer: New York, NY, USA, 2001; pp. 321-348.

7. Warren, S.D.; Mitášová, H.; Hohmann, M.G.; Landsberger, S.; Iskander, F.Y.; Ruzycki, T.S.; Senseman, G.M. Validation of a 3-D enhancement of the Universal Soil Loss Equation for prediction of soil erosion and sediment deposition. Catena 2005, 64, 281-296. [CrossRef]

8. Ferro, V.; Porto, P. Sediment delivery distributed (SEDD) model. J. Hydrol. Eng. 2000, 5, 411-422. [CrossRef]

9. Ferro, V.; Minacapilli, M. Sediment delivery processes at basin scale. Hydrol. Sci. J. 1995, 40, 703-717. [CrossRef]

10. Fernandez, C.; Wu, J.Q.; McCool, D.K.; Stöckle, C.O. Estimating water erosion and sediment yield with GIS, RUSLE, and SEDD. J. Soil Water Conserv. 2003, 58, 128-136.

11. Fu, G.; Chen, S.; McCool, D.K. Modeling the impacts of no-till practice on soil erosion and sediment yield with RUSLE, SEDD, and ArcView GIS. Soil Tillage Res. 2006, 85, 38-49. [CrossRef]

12. Tanyaş, H.; Kolat, Ç.; Süzen, M.L. A new approach to estimate cover-management factor of RUSLE and validation of RUSLE model in the watershed of Kartalkaya Dam. J. Hydrol. 2015, 528, 584-598. [CrossRef]

13. Burguet, M.; Taguas, E.V.; Gómez, J.A. Exploring calibration strategies of the SEDD model in two olive orchard catchments. Geomorphology 2017, 290, 17-28. [CrossRef]

14. Olii, M.R.; Kironoto, B.A.; Yulistiyanto, B.; Sunjoto, S. Estimating spatially distributed of sediment yield using GIS-RUSLE-SEDD model in catchment of reservoir in Java. In Multi-Perspective Water for Sustainable Development, Proceedings of the 21st International Association for Hydro-Environment Engineering and Research-Asia Pacific Division (IAHR-APD) Congress, Yohyakarta, Indonesia, 2-5 September 2018; IAHR-APD: Gyeonggi-Do, Korea, 2018; pp. 351-358.

15. Neter, J.; Wasserman, W.; Whitmore, G.A. Applied Statistics, 4th ed.; Allyn and Bacon: Boston, MA, USA, 1993; pp. 153-155.

16. Zhang, G.; Wang, Y.; Wei, H.; Chen, Y. Examining headway distribution models with urban freeway loop event data. Transp. Res. Rec. 2007, 1999, 141-149. [CrossRef]

17. Proschan, F. Theoretical explanation of observed decreasing failure rate. Technometrics 2000, 42, 7-11. [CrossRef]

18. McGuire, K.J.; McDonnell, J.J.; Weiler, M.; Kendall, C.; McGlynn, B.L.; Welker, J.M.; Seibert, J. The role of topography on catchment-scale water residence time. Water Resour. Res. 2005, 41, 1-14. [CrossRef]

19. Shipley, B.; Vile, D.; Garnier, É. From plant traits to plant communities: A statistical mechanistic approach to biodiversity. Science 2006, 314, 812-814. [CrossRef] [PubMed]

20. Morgan, R.P.C.; Quinton, J.N.; Smith, R.E.; Govers, G.; Poesen, J.W.A.; Auerswald, K.; Chisci, G.; Torri, D.; Styczen, M.E.; Folly, A.J.V. The European Soil Erosion Model (EUROSEM): Documentation and User Guide; Silsoe College, Cranfield University: Bedford, UK, 1998; pp. 35-36.

21. Mendenhall, W.; Sincich, T. A Second Course in Business Statistics: Regression Analysis, 3rd ed.; Dellen Publishing Company: San Francisco, CA, USA, 1989; pp. 37-40.

22. Ferro, V. Further remarks on a distributed approach to sediment delivery. Hydrol. Sci. J. 1997, 42, 633-647. [CrossRef]

23. Ferro, V.; Porto, P.; Tusa, G. Testing a distributed approach for modelling sediment delivery. Hydrol. Sci. J. 1998, 43, 425-442. [CrossRef] 
24. Ferro, V.; Di Stefano, C.; Minacapilli, M.; Santoro, M. Calibrating the SEDD model for Sicilian ungauged basins. In Erosion Prediction in Ungauged Basins: Integrating Methods and Techniques, Proceedings of the Symposium HS01 Held During International Union of Geodesy and Geophysics (IUGG) 2003, Sapporo, Japan, 30 June-11 July 2003; IAHS-AISH Publication: Wallingford, Oxfordshire, UK, 2003; Volume 279, pp. 151-161.

25. Di Stefano, C.; Ferro, V.; Minacapilli, M. Testing the SEDD model in Sicilian basins. In Sediment. Budgets 2, Proceedings of the Symposium S1 Held during the Seventh International Association of Hydrological Sciences (IAHS) Scientific Assembly, Foz do Iguaçu, Brazil, 3-9 April 2005; IAHS-AISH Publication: Wallingford, Oxfordshire, UK, 2005; Volume 292, pp. 152-161.

26. Di Stefano, C.; Ferro, V. Testing the Modified Sediment Delivery Model (MOSEDD) at SPA2 Experimental Basin, Sicily (Italy). Land Degrad. Dev. 2017, 28, 1557-1567. [CrossRef]

27. Di Stefano, C.; Ferro, V. Testing Sediment Connectivity at the Experimental SPA2 Basin, Sicily (Italy). Land Degrad. Dev. 2017, 28, 1992-2000. [CrossRef]

28. Di Stefano, C.; Ferro, V. Modelling sediment delivery using connectivity components at the experimental SPA2 basin, Sicily (Italy). J. Mt. Sci. 2018, 15, 1868-1880. [CrossRef]

29. Di Stefano, C.; Ferro, V. Assessing sediment connectivity in dendritic and parallel calanchi systems. Catena 2019, 172, 647-654. [CrossRef]

30. Caraballo-Arias, N.A.; Di Stefano, C.; Ferro, V. Morphological characterization of calanchi (badland) hillslope connectivity. Land Degrad. Dev. 2018, 29, 1190-1197. [CrossRef]

31. Yan, R.; Zhang, X.; Yan, S.; Chen, H. Estimating soil erosion response to land use/cover change in a catchment of the Loess Plateau, China. Int. Soil Water Conserv. Res. 2018, 6, 13-22. [CrossRef]

32. Porto, P.; Cogliandro, V.; Callegari, G. Exploring the performance of the SEDD model to predict sediment yield in eucalyptus plantations. Long-term results from an experimental catchment in Southern Italy. In Institute of Physics (IOP) Conference Series: Earth and Environmental Science, Proceedings of the 3rd International Conference Environment and Sustainable Development of Territories: Ecological Challenges of the 21st Century, Kazan, Russia, 27-29 September 2017; IOP Publishing: Bristol, UK, 2018; Volume 107.

33. Di Stefano, C.; Ferro, V.; Porto, P. Linking sediment yield and caesium-137 spatial distribution at basin scale. J. Agric. Eng. Res. 1999, 74, 41-62. [CrossRef]

34. Di Stefano, C.; Ferro, V.; Rizzo, S. Assessing soil erosion in a small Sicilian basin by caesium-137 measurements and a simplified mass balance model. Hydrol. Sci. J. 2000, 45, 817-832. [CrossRef]

35. He, Q.; Walling, D.E. Testing distributed soil erosion and sediment delivery models using 137Cs measurements. Hydrol. Proc. 2003, 17, 901-916. [CrossRef]

36. Di Stefano, C.; Ferro, V.; Porto, P.; Rizzo, S. Testing a spatially distributed sediment delivery model (SEDD) in a forested basin by cesium-137 technique. J. Soil Water Conserv. 2005, 60, 148-157.

37. Porto, P.; Walling, D.E. Use of caesium-137 measurements and long-term records of sediment load to calibrate the sediment delivery component of the SEDD model and explore scale effect: Examples from southern Italy. J. Hydrol. Eng. 2015, 20. [CrossRef]

38. Di Stefano, C.; Ferro, V.; Porto, P. Modelling sediment delivery processes by a stream tube approach. Hydrol. Sci. 1999, 44, 725-742. [CrossRef]

39. Di Stefano, C.; Ferro, V.; Porto, P. Length slope factors for applying the revised universal soil loss equation at basin scale in southern Italy. J. Agric. Eng. Res. 2000, 75, 349-364. [CrossRef]

40. Di Stefano, C.; Ferro, V.; Porto, P.; Tusa, G. Slope curvature influence on soil erosion and deposition processes. Water Resour. Res. 2000, 36, 607-617. [CrossRef]

41. Zhao, Z.; Thien, L.C.; Yang, Q.; Rees, H.W.; Benoy, G.; Xing, Z.; Meng, F.-R. Model prediction of soil drainage classes based on digital elevation model parameters and soil attributes from coarse resolution soil maps. Can. J. Soil Sci. 2008, 88, 787-799. [CrossRef]

42. Vigiak, O.; Borselli, L.; Newham, L.T.H.; McInnes, J.; Roberts, A.M. Comparison of conceptual landscape metrics to define hillslope-scale sediment delivery ratio. Geomorphology 2012, 138, 74-88. [CrossRef]

43. Jain, M.K.; Kothyari, U.C. Estimation of soil erosion and sediment yield using GIS. Hydrol. Sci. 2000, 4, 771-786. [CrossRef]

44. Son, K.I.; Lee, J.J. Prediction of erosion and deposition in a mountainous basin. In Sediment. Budgets 2, Proceedings of Symposium S1 Held during the Seventh International Association of Hydrological Sciences (IAHS) Scientific Assembly, Foz do Iguaçu, Brazil, 3-9 April 2005; IAHS-AISH Publication: Wallingford, Oxfordshire, UK, 2005; Volume 292, pp. 152-161, 185-193. 
45. Mutua, B.M.; Klik, A.; Loiskandl, W. Modelling soil erosion and sediment yield at a catchment scale: The case of Masinga catchment, Kenya. Land Degrad. Dev. 2006, 17, 557-570. [CrossRef]

46. Di Stefano, C.; Ferro, V. Evaluation of the SEDD model for predicting sediment yield at the Sicilian experimental SPA2 basin. Earth Surf. Proc. Landf. 2007, 32, 1094-1109. [CrossRef]

47. Bhattarai, R.; Dutta, D. Estimation of soil erosion and sediment yield using GIS at catchment scale. Water Resour. Manag. 2007, 21, 1635-1647. [CrossRef]

48. Drzewiecki, W.; Mularz, S. Simulation of water soil erosion effects on sediment delivery to Dobczyce Reservoir. Int. Arch. Photogramm. Remote Sens. Spat. Inf. Sci.-ISPRS Arch. 2008, 37, 787-794.

49. Vigiak, O.; Newham, L.T.H.; Whitford, J.; Melland, A.; Borselli, L. Comparison of landscape approaches to define spatial patterns of hillslope-scale sediment delivery ratio. In I14. Biophysical Modelling to Prioritise Catchment Management Effort, Proceedings of the 18th World IMACS Congress and MODSIM09 International Congress on Modelling and Simulation. Modelling and Simulation Society of Australia and New Zealand and International Association for Mathematics and Computers in Simulation, Cairns, Australia, 13-17 July 2009; Anderssen, R.S., Braddock, R.D., Newham, L.T.H., Eds.; Modelling and Simulation Society of Australia and New Zealand (MSSANZ): Canberra, Australia, 2009; pp. 4064-4070.

50. Ali, K.F.; De Boer, D.H. Spatially distributed erosion and sediment yield modeling in the upper Indus River basin. Water Resour. Res. 2010, 46. [CrossRef]

51. Chen, L.; Qian, X.; Shi, Y. Critical Area Identification of Potential Soil Loss in a Typical Watershed of the Three Gorges Reservoir Region. Water Resour. Manag. 2011, 25, 3445-3463. [CrossRef]

52. Capra, A.; Ferro, V.; Porto, P.; Scicolone, B. Quantifying interrill and ephemeral gully erosion in a small Sicilian basin. Z. Geomorphol. 2012, 56 (Suppl. 1), 9-25. [CrossRef]

53. Saygın, S.D.; Ozcan, A.U.; Basaran, M.; Timur, O.B.; Dolarslan, M.; Yılman, F.E.; Erpul, G. The combined RUSLE/SDR approach integrated with GIS and geostatistics to estimate annual sediment flux rates in the semi-arid catchment, Turkey. Environ. Earth Sci. 2014, 71, 1605-1618. [CrossRef]

54. Lee, S.E.; Kang, S.H. Geographic information system-coupling sediment delivery distributed modeling based on observed data. Water Sci. Technol. 2014, 70, 495-501. [CrossRef] [PubMed]

55. Kang, S.H. GIS-based sediment transport in Asian monsoon region. Environ. Earth Sci. 2014, 73, 221-230. [CrossRef]

56. Pohlert, T. Projected climate change impact on soil erosion and sediment yield in the river Elbe catchment. In Sediment Matters; Heininger, P., Cullmann, J., Eds.; Springer International Publishing: Cham, Switzerland, 2015; pp. 97-108.

57. Taguas, E.V.; Guzmán, E.; Guzmán, G.; Vanwalleghem, T.; Gómez, J.A. Characteristics and importance of rill and gully erosion: A case study in a small catchment of a marginal olive grove. Cuadernos Investigacion Geografica 2015, 41, 107-126. [CrossRef]

58. Batista, P.V.G.; Silva, M.L.N.; Silva, B.P.C.; Curi, N.; Bueno, I.T.; Acérbi Júnior, F.W.; Davies, J.; Quinton, J. Modelling spatially distributed soil losses and sediment yield in the upper Grande River Basin-Brazil. Catena 2017, 157, 139-150. [CrossRef]

59. Di Stefano, C.; Ferro, V.; Palazzolo, E.; Panno, M. Sediment delivery processes and agricultural non-point pollution in a Sicilian Basin. J. Agric. Eng. Res. 2000, 77, 103-112. [CrossRef]

60. Di Stefano, C.; Ferro, V. Linking clay enrichment and sediment delivery processes. Biosyst. Eng. 2002, 81, 465-479. [CrossRef]

61. Kothyari, U.C.; Jain, M.K.; Ranga Raju, K.G. Estimation of temporal variation of sediment yield using GIS. Hydrol. Sci. 2002, 47, 693-706. [CrossRef]

62. Di Stefano, C.; Ferro, V.; Palazzolo, E.; Panno, M. Sediment delivery processes and chemical transport in a small forested basin. Hydrol. Sci. 2005, 50, 697-712. [CrossRef]

63. Huang, J.; Li, Q.; Tu, Z.; Pan, C.; Zhang, L.; Ndokoye, P.; Lin, J.; Hong, H. Quantifying land-based pollutant loads in coastal area with sparse data: Methodology and application in China. Ocean Coast. Manag. 2013, 81, 14-28. [CrossRef]

64. Di Piazza, G.V.; Di Stafano, C.; Ferro, V. Modelling the effects of a bushfire on erosion in a Mediterranean basin. Hydrol. Sci. 2007, 52, 1253-1270. [CrossRef]

65. Kinsey-Henderson, A.E.; Post, D.A. Evaluation of the scale dependence of a spatially-explicit hillslope sediment delivery ratio model. In Proceedings of the 3rd International Congress on Environmental Modelling and Software (iEMSs), Burlington, VT, USA, 1 July 2006; BYU ScholarsArchive: Provo, UT, USA, 2006; p. 213. 
66. Post, D.A.; Kinsey-Henderson, A.E.; Bartley, R.; Hawdon, A. Deriving a spatially-explicit hillslope sediment delivery ratio model based on the travel time of water across a hillslope. In Proceedings of the 3rd International Congress on Environmental Modelling and Software (iEMSs), Burlington, VT, USA, 1 July 2006; BYU ScholarsArchive: Provo, UT, USA, 2006; p. 213.

67. Zhao, Z.; Chow, T.L.; Rees, H.W.; Yang, Q.; Xing, Z.; Meng, F.-R. Predict soil texture distributions using an artificial neural network model. Comput. Electron. Agric. 2009, 65, 36-48. [CrossRef]

68. López-Vicente, M.; Navas, A. Relating soil erosion and sediment yield to geomorphic features and erosion processes at the catchment scale in the Spanish Pre-Pyrenees. Environ. Earth Sci. 2010, 61, 143-158. [CrossRef]

69. Tamene, L.; Le, Q.B.; Vlek, P.L.G. A Landscape Planning and Management Tool for Land and Water Resources Management: An Example Application in Northern Ethiopia. Water Resour. Manag. 2014, 28, 407-424. [CrossRef]

70. Zhao, G.; Kondolf, G.M.; Mu, X.; Han, M.; He, Z.; Rubin, Z.; Wang, F.; Gao, P.; Sun, W. Sediment yield reduction associated with land use changes and check dams in a catchment of the Loess Plateau, China. Catena 2017, 148, 126-137. [CrossRef]

71. Tamene, L.; Adimassu, Z.; Aynekulu, E.; Yaekob, T. Estimating landscape susceptibility to soil erosion using a GIS-based approach in Northern Ethiopia. Int. Soil Water Conserv. Res. 2017, 5, 221-230. [CrossRef]

72. Xu, Y.; Tang, H.; Wang, B.; Chen, J. Effects of landscape patterns on soil erosion processes in a mountain-basin system in the North China. Nat. Hazard. 2017, 87, 1567-1585. [CrossRef]

73. Walling, D.E.; He, Q. Use of fallout $137 \mathrm{Cs}$ measurements for validating and calibrating soil erosion and sediment delivery models. IAHS-AISH Publ. 1998, 249, 267-278.

74. De Roo, A.P.J. Modelling runoff and sediment transport in catchments using GIS. Hydrol. Proc. 1998, 12, 905-922. [CrossRef]

75. Di Stefano, C.; Ferro, V.; Porto, P. Applying the bootstrap technique for studying soil redistribution by caesium-137 measurements at basin scale. Hydrol. Sci. 2000, 45, 171-183. [CrossRef]

76. Lu, X.X.; Higgitt, D.L. Sediment delivery to the Three Gorges 2: Local response. Geomorphology 2001, 41, 157-169. [CrossRef]

77. Prosser, I.P.; Rutherfurd, I.D.; Olley, J.M.; Young, W.J.; Wallbrink, P.J.; Moran, C.J. Large-scale patterns of erosion and sediment transport in river networks, with examples from Australia. Mar. Freshw. Res. 2001, 52, 81-99. [CrossRef]

78. Merritt, W.S.; Letcher, R.A.; Jakeman, A.J. A review of erosion and sediment transport models. Environ. Model. Softw. 2003, 18, 761-799. [CrossRef]

79. Kaur, R.; Singh, O.; Srinivasan, R.; Das, S.N.; Mishra, K. Comparison of a subjective and a physical approach for identification of priority areas for soil and water management in a watershed-A case study of Nagwan watershed in Hazaribagh District of Jharkhand, India. Environ. Model. Assess. 2004, 9, 115-127. [CrossRef]

80. Phillips, J.D.; Slattery, M.C.; Musselman, Z.A. Dam-to-delta sediment inputs and storage in the lower trinity river, Texas. Geomorphology 2004, 62, 17-34. [CrossRef]

81. Amore, E.; Modica, C.; Nearing, M.A.; Santoro, V.C. Scale effect in USLE and WEPP application for soil erosion computation from three Sicilian basins. J. Hydrol. 2004, 293, 100-114. [CrossRef]

82. Scanlon, T.M.; Kiely, G.; Xie, Q. A nested catchment approach for defining the hydrological controls on non-point phosphorus transport. J. Hydrol. 2004, 291, 218-231. [CrossRef]

83. Lu, H.; Moran, C.J.; Sivapalan, M. A theoretical exploration of catchment-scale sediment delivery. Water Resour. Res. 2005, 41, 1-15. [CrossRef]

84. Parsons, A.J.; Wainwright, J.; Brazier, R.E.; Powell, D.M. Is sediment delivery a fallacy? Earth Surf. Proc. Landf. 2006, 31, 1325-1328. [CrossRef]

85. Verstraeten, G.; Prosser, I.P.; Fogarty, P. Predicting the spatial patterns of hillslope sediment delivery to river channels in the Murrumbidgee catchment, Australia. J. Hydrol. 2007, 334, 440-454. [CrossRef]

86. Grauso, S.; Pagano, A.; Fattoruso, G.; De Bonis, P.; Onori, F.; Regina, P.; Tebano, C. Relations between climatic-geomorphological parameters and sediment yield in a mediterranean semi-arid area (Sicily, Southern Italy). Environ. Geol. 2008, 54, 219-234. [CrossRef]

87. Lu, H.; Richards, K. Sediment delivery: New approaches to modelling an old problem. In River Confluences, Tributaries and the Fluvial Network; Rice, S.P., Roy, A.G., Rhoads, B.L., Eds.; John Wiley \& Sons Ltd.: Chichester, UK, 2008; pp. 337-366.

88. Krishna Bahadur, K.C. Mapping soil erosion susceptibility using remote sensing and GIS: A case of the Upper Nam Wa Watershed, Nan Province, Thailand. Environ. Geol. 2009, 57, 695-705. [CrossRef] 
89. Ding, J.; Richards, K. Preliminary modelling of sediment production and delivery in the Xihanshui River basin, Gansu, China. Catena 2009, 79, 277-287. [CrossRef]

90. Verstraeten, G.; Rommens, T.; Peeters, I.; Poesen, J.; Govers, G.; Lang, A. A temporarily changing Holocene sediment budget for a loess-covered catchment (central Belgium). Geomorphology 2009, 108, 24-34. [CrossRef]

91. Higgitt, D. Continental-scale river basins. In Sediment Cascades: An Integrated Approach; Burt, T.P., Allison, R.J., Eds.; John Wiley \& Sons, Ltd.: Chichester, UK, 2009; p. 397.

92. Zhao, Z.; Yang, Q.; Benoy, G.; Chow, T.L.; Xing, Z.; Rees, H.W.; Meng, F.-R. Using artificial neural network models to produce soil organic carbon content distribution maps across landscapes. Can. J. Soil Sci. 2010, 90, 75-87. [CrossRef]

93. Alatorre, L.C.; Beguería, S.; García-Ruiz, J.M. Regional scale modeling of hillslope sediment delivery: A case study in the Barasona Reservoir watershed (Spain) using WATEM/SEDEM. J. Hydrol. 2010, 391, 109-123. [CrossRef]

94. Arekhi, S.; Shabani, A.; Alavipanah, S.K. Evaluation of integrated KW-GIUH and MUSLE models to predict sediment yield using geographic information system (GIS) (Case study: Kengir watershed, Iran). Afr. J. Agric. Res. 2011, 6, 4185-4198.

95. Hicks, D.M.; Shankar, U.; Mckerchar, A.I.; Basher, L.; Lynn, I.; Page, M.; Jessen, M. Suspended sediment yields from New Zealand rivers. J. Hydrol. N. Z. 2011, 50, 81-142.

96. Walling, D.E.; Wilkinson, S.H.; Horowitz, A.J. Catchment erosion, sediment delivery, and sediment quality. In Treatise on Water Science; Wilderer, P., Rogers, P., Uhlenbrook, S., Frimmel, F., Hanaki, K., Vereijken, T., Eds.; Elsevier: Amsterdam, The Netherlands, 2011; Volume 2, p. 322.

97. Grismer, M.E. Erosion modelling for land management in the Tahoe basin, USA: Scaling from plots to forest catchments. Hydrol. Sci. 2012, 57, 878-900. [CrossRef]

98. Chowdary, V.M.; Chakraborthy, D.; Jeyaram, A.; Murthy, Y.V.N.K.; Sharma, J.R.; Dadhwal, V.K. Multi-Criteria Decision Making Approach for Watershed Prioritization Using Analytic Hierarchy Process Technique and GIS. Water Resour. Manag. 2013, 27, 3555-3571. [CrossRef]

99. Park, W.S.; Hong, S.H.; Hwan, A.C.; Hyun, C. Assessment of soil loss in irrigation reservoir based on GIS. J. Korean Soc. Surv. Geod. Photogramm. Cartogr. 2013, 31, 439-446. [CrossRef]

100. Zhao, Z.; MacLean, D.A.; Bourque, C.P.-A.; Swift, D.E.; Meng, F.-R. Generation of soil drainage equations from an artificial neural network-analysis approach. Can. J. Soil Sci. 2013, 93, 329-342. [CrossRef]

101. Wu, L.; Long, T.-Y.; Liu, X.; Ma, X.-Y. Modeling impacts of sediment delivery ratio and land management on adsorbed non-point source nitrogen and phosphorus load in a mountainous basin of the Three Gorges reservoir area, China. Environ. Earth Sci. 2013, 70, 1405-1422. [CrossRef]

102. Son, K.-I.; Woo, K.-S.; Kang, Y.-G.; Kim, K.-M.; Son, G.-C. Characteristics of nonpoint source erosion from burned mountain basin. Adv. Mater. Res. 2013, 610, 2787-2790. [CrossRef]

103. Dumitriu, D. Source area lithological control on sediment delivery ratio in Trotuş drainage basin (Eastern Carpathians). Geogr. Fisica Din. Quat. 2014, 37, 91-100.

104. Karydas, C.G.; Panagos, P.; Gitas, I.Z. A classification of water erosion models according to their geospatial characteristics. Int. J. Digit. Earth 2014, 7, 229-250. [CrossRef]

105. Kim, S.M.; Jang, T.I.; Kang, M.S.; Im, S.J.; Park, S.W. GIS-based lake sediment budget estimation taking into consideration land use change in an urbanizing catchment area. Environ. Earth Sci. 2014, 71, 2155-2165. [CrossRef]

106. Zheng, M.; Liao, Y.; He, J. Sediment delivery ratio of single flood events and the influencing factors in a headwater basin of the Chinese loess plateau. PLoS ONE 2014, 9, e112594. [CrossRef]

107. Bezak, N.; Rusjan, S.; Petan, S.; Sodnik, J.; Mikoš, M. Estimation of soil loss by the WATEM/SEDEM model using an automatic parameter estimation procedure. Environ. Earth Sci. 2015, 74, 5245-5261. [CrossRef]

108. Gajbhiye, S.; Mishra, S.K.; Pandey, A. Simplified sediment yield index model incorporating parameter curve number. Arab. J. Geosci. 2015, 8, 1993-2004. [CrossRef]

109. Mokhtari, A.R.; Garousi Nezhad, S. A modified equation for the downstream dilution of stream sediment anomalies. J. Geochem. Explor. 2015, 159, 185-193. [CrossRef]

110. Strehmel, A.; Schönbrodt-Stitt, S.; Buzzo, G.; Dumperth, C.; Stumpf, F.; Zimmermann, K.; Bieger, K.; Behrens, T.; Schmidt, K.; Bi, R.; et al. Assessment of geo-hazards in a rapidly changing landscape: The three Gorges Reservoir Region in China. Environ. Earth Sci. 2015, 74, 4939-4960. [CrossRef]

111. Zhang, X.; Wu, S.; Cao, W.; Guan, J.; Wang, Z. Dependence of the sediment delivery ratio on scale and its fractal characteristics. Int. J. Sediment. Res. 2015, 30, 338-343. [CrossRef] 
112. Choi, H. Analysis of the adequacy check dam according to soil loss using rusle. J. Korean Soc. Surv. Geod. Photogramm. Cartogr. 2016, 34, 515-524. [CrossRef]

113. Duraes, M.F.; de Mello, C.R.; Beskow, S. Sediment yield in Paraopeba River Basin-MG, Brazil. Int. J. River Basin Manag. 2016, 14, 367-377. [CrossRef]

114. Golosov, V.; Collins, A.L.; Tang, Q.; Zhang, X.; Zhou, P.; He, X.; Wen, A. Sediment transfer at different spatial and temporal scales in the Sichuan Hilly Basin, China: Synthesizing data from multiple approaches and preliminary interpretation in the context of climatic and anthropogenic drivers. Sci. Total Environ. 2017, 598, 319-329. [CrossRef]

115. Her, Y.; Heatwole, C. HYSTAR Sediment Model: Distributed Two-Dimensional Simulation of Watershed Erosion and Sediment Transport Using Time-Area Routing. J. Am. Water Resour. Assoc. 2016, 52, 376-396. [CrossRef]

116. Calsamiglia, A.; Fortesa, J.; García-Comendador, J.; Lucas-Borja, M.E.; Calvo-Cases, A.; Estrany, J. Spatial patterns of sediment connectivity in terraced lands: Anthropogenic controls of catchment sensitivity. Land Degrad. Dev. 2018, 29, 1198-1210. [CrossRef]

117. Choi, H.; Kim, G. Estimating unsteady soil loss due to rainfall impact according to rim fire at California. J. Korean Soc. Surv. Geod. Photogramm. Cartogr. 2017, 35, 269-279.

118. Conte, P.; Di Stefano, C.; Ferro, V.; Laudicina, V.A.; Palazzolo, E. Assessing hydrological connectivity inside a soil by fast-field-cycling nuclear magnetic resonance relaxometry and its link to sediment delivery processes. Environ. Earth Sci. 2017, 76. [CrossRef]

119. Pietroń, J.; Chalov, S.R.; Chalova, A.S.; Alekseenko, A.V.; Jarsjö, J. Extreme spatial variability in riverine sediment load inputs due to soil loss in surface mining areas of the Lake Baikal basin. Catena 2017, 152, 82-93. [CrossRef]

120. Shahrestani, S.; Mokhtari, A.R. Improved detection of anomalous catchment basins by incorporating drainage density in dilution correction of geochemical residuals. Geochem. Exp. Environ. Anal. 2017, 17, 194-203. [CrossRef]

121. Mašíček, T.; Dufková, J.K.; Zámečník, T. Evaluation of erosion rates in cadastral area Rovečné (Moravia) using GIS tools. Eur. Countrys. 2017, 9, 51-76. [CrossRef]

122. Ondráčková, L.; Máčka, Z. Geomorphic (dis)connectivity in a middle-mountain context: Human interventions in the landscape modify catchment-scale sediment cascades. Area 2019, 51, 113-125. [CrossRef]

123. Cho, S.J.; Wilcock, P.; Hobbs, B. Topographic filtering simulation model for sediment source apportionment. Geomorphology 2018, 309, 1-19. [CrossRef]

124. Grauso, S.; Pasanisi, F.; Tebano, C. Assessment of a simplified connectivity index and specific sediment potential in river basins by means of geomorphometric tools. Geosciences 2018, 8, 48. [CrossRef]

125. James, L.A. Ten conceptual models of large-scale legacy sedimentation-A review. Geomorphology 2018, 317, 199-217. [CrossRef]

126. Le Roux, J.J. Sediment Yield Potential in South Africa's Only Large River Network without a Dam: Implications for Water Resource Management. Land Degrad. Dev. 2018, 29, 765-775. [CrossRef]

127. Alewell, C.; Borrelli, P.; Meusburger, K.; Panagos, P. Using the USLE: Chances, challenges and limitations of soil erosion modelling. Int. Soil Water Conserv. Res. 2019, 7, 203-225. [CrossRef]

128. Marques, V.S.; Ceddia, M.B.; Antunes, M.A.H.; Carvalho, D.F.; Anache, J.A.A.; Rodrigues, D.B.B.; Oliveira, P.T.S. USLE K-factor method selection for a tropical catchment. Sustainability 2019, 11, 1840. [CrossRef]

129. Lu, X.; Li, Y.; Washington-Allen, R.A.; Li, Y. Structural and sedimentological connectivity on a rilled hillslope. Sci. Total Environ. 2019, 655, 1479-1494. [CrossRef] [PubMed]

130. Diwediga, B.; Le, Q.B.; Agodzo, S.K.; Tamene, L.D.; Wala, K. Modelling soil erosion response to sustainable landscape management scenarios in the Mo River Basin (Togo, West Africa). Sci. Total Environ. 2018, 625, 1309-1320. [CrossRef] [PubMed]

(C) 2020 by the authors. Licensee MDPI, Basel, Switzerland. This article is an open access article distributed under the terms and conditions of the Creative Commons Attribution (CC BY) license (http://creativecommons.org/licenses/by/4.0/). 